\title{
TUNDRITE-(Ce) FROM MONT SAINT-HILAIRE, QUEBEC: CRYSTAL-STRUCTURE ANALYSIS AND SPECIES CHARACTERIZATION
}

\author{
JOEL D. GRICE ${ }^{\S}$, RALPH ROWE AND GLENN POIRIER \\ Research Division, Canadian Museum of Nature, P.O. Box 3443, Station D, Ottawa, Ontario KIP 6P4, Canada \\ QUINTIN WIGHT \\ 525 Fielding Drive, Ottawa, Ontario K1V 7G7, Canada
}

\begin{abstract}
Tundrite-(Ce), ideally $\mathrm{Na}_{2} \mathrm{Ce}_{2} \mathrm{TiO}_{2}\left(\mathrm{SiO}_{4}\right)\left(\mathrm{CO}_{3}\right)_{2}$, has been found recently in the Mont Saint-Hilaire quarry, Quebec. It occurs as yellow-green, bladed, singly terminated crystals up to $9 \mathrm{~mm}$ in length. Minerals associated with tundrite-(Ce) are aegirine, analcime, an astrophyllite-group mineral, catapleiite, a eudialyte-group mineral, gonnardite, mangan-neptunite, monazite-(Ce), natrolite, rhodochrosite, sphalerite and vinogradovite. Tundrite-(Ce) is triclinic, space group $P \overrightarrow{1}$, with the following unit-cell parameters, refined from powder-diffraction data: a 7.5702(6), $b$ 13.949(2), c 5.0235(5) $\AA, \alpha 100.19(1), \beta 70.88(1), \gamma 101.26(1)^{\circ}$, $V 487.91(6) \AA^{3}$ and $Z=2$. Crystals are tabular on $\{010\}$ and elongate on [001], with pinacoid forms: $\{100\},\{010\},\{201\}$ and $\{\overline{1} 01\}$. Electron-microprobe analyses give the average and ranges: $\mathrm{Na}_{2} \mathrm{O} 9.44(9.07-9.66), \mathrm{CaO} 0.34(0.16-0.42), \mathrm{La}_{2} \mathrm{O}_{3} 16.12$ (15.26-17.95), $\mathrm{Ce}_{2} \mathrm{O}_{3} 27.01$ (25.41-28.56), $\mathrm{Pr}_{2} \mathrm{O}_{3} 2.13$ (1.72-2.38), $\mathrm{Nd}_{2} \mathrm{O}_{3}$ 6.16 (5.61-6.58), $\mathrm{Sm}_{2} \mathrm{O}_{3}\left(0.38(0.18-0.73), \mathrm{TiO}_{2} 11.17\right.$ (10.73-11.93), $\mathrm{Nb}_{2} \mathrm{O}_{5} 2.30$ (1.14-3.11), $\mathrm{Ta}_{2} \mathrm{O}_{5} 0.07$ (0.00-0.15), $\mathrm{SiO}_{2} 9.32$ (9.10-9.54), $\mathrm{CO}_{2} 13.91$ (TGA), $\mathrm{H}_{2} \mathrm{O} 0.36$ (TGA), for a total of $98.80(97.43-100.17) \mathrm{wt} . \%$. The empirical formula based on the crystal-structure analysis, ideally showing 24 oxygen atoms, is $2\left[\left(\mathrm{Na}_{1.906} \mathrm{Ca}_{0.039}\right)_{\Sigma 1.945}\left(\mathrm{Ce}_{1.030} \mathrm{La}_{0.621} \mathrm{Nd}_{0.229} \mathrm{Pr}_{0.081} \mathrm{Sm}_{0.014}\right)_{\Sigma 1.975}\left(\mathrm{Ti}_{0.875} \mathrm{Nb}_{0.109}\right)_{\Sigma 0.984} \mathrm{O}_{2} \mathrm{H}_{0.250}\left(\mathrm{Si}_{0.971} \mathrm{O}_{4}\right)\left(\mathrm{C}_{0.989} \mathrm{O}_{3}\right)_{2}\right]$. The structure has been refined to an $R$ index of $2.7 \%$ for 2827 unique reflections. The structure has three chemically distinct layers parallel to (010): (1) a Na-Ti-Si-O slab, (2) a $\mathrm{Ce}-\mathrm{C}-\mathrm{O}$ slab and (3) a $\mathrm{Na}-\mathrm{O}$ slab. Slabs are cross-linked by independent $\left[\mathrm{CO}_{3}\right]^{2-}$ and $\left[\mathrm{SiO}_{4}\right]^{4-}$ groups. Minor amounts of $\mathrm{OH}$ are present to ensure charge balance as a result of the substitutions $\mathrm{Nb} \leftrightarrow$ Ti and $\mathrm{Ca} \leftrightarrow \mathrm{REE}$.
\end{abstract}

Keywords: tundrite-(Ce), crystal structure, rare-earth elements, chemical composition, infrared spectroscopy, hydrogen, Mont Saint-Hilaire, Quebec.

\section{SOMMAIRE}

Nous avons trouvé récemment des cristaux de tundrite-(Ce), dont la formule idéale est $\mathrm{Na}_{2} \mathrm{Ce}_{2} \mathrm{TiO}_{2}\left(\mathrm{SiO}_{4}\right)\left(\mathrm{CO}_{3}\right)_{2}$, à la carrière dans le flanc du mont Saint-Hilaire, Québec. Elle se présente en cristaux jaune-verts, en lames terminées atteignant une longueur de $9 \mathrm{~mm}$. Lui sont associés aegyrine, analcime, un minéral du groupe de l'astrophyllite, catapléiite, un minéral du groupe de l'eudialyte, gonnardite, mangan-neptunite, monazite-(Ce), natrolite, rhodochrosite, sphalérite et vinogradovite. La tundrite-(Ce) est triclinique, groupe spatial $P \overline{1}$, avec les paramètres réticulaires suivants, affinés avec les données en diffraction $\mathrm{X}$ obtenues sur poudre: $a$ 7.5702(6), $b$ 13.949(2), c 5.0235(5) $\AA$, $\alpha 100.19(1), \beta 70.88(1), \gamma 101.26(1)^{\circ}, V 487.91(6) \AA^{3}$ et $Z=2$. Les cristaux sont tabulaires sur $\{010\}$ et allongés selon [001], avec formes pinacoïdales $\{100\},\{010\},\{201\}$ et $\{\overline{1} 01\}$. Les analyses effectuées avec une microsonde électronique ont donné les valeurs moyennes et les intervalles suivants: $\mathrm{Na}_{2} \mathrm{O} 9.44$ (9.07-9.66), $\mathrm{CaO} 0.34$ (0.16-0.42), $\mathrm{La}_{2} \mathrm{O}_{3} 16.12$ (15.26-17.95), $\mathrm{Ce}_{2} \mathrm{O}_{3} 27.01$ (25.41-28.56), $\mathrm{Pr}_{2} \mathrm{O}_{3} 2.13$ (1.72-2.38), $\mathrm{Nd}_{2} \mathrm{O}_{3} 6.16$ (5.61-6.58), $\mathrm{Sm}_{2} \mathrm{O}_{3}\left(0.38(0.18-0.73), \mathrm{TiO}_{2} 11.17(10.73-11.93), \mathrm{Nb}_{2} \mathrm{O}_{5} 2.30(1.14-3.11), \mathrm{Ta}_{2} \mathrm{O}_{5} 0.07(0.00-0.15), \mathrm{SiO}_{2} 9.32(9.10-9.54), \mathrm{CO}_{2}\right.$ 13.91 (TGA), $\mathrm{H}_{2} \mathrm{O} 0.36$ (TGA), pour un total de 98.80 (97.43-100.17)\% (poids). La formule empirique fondée sur les résultats de l'analyse structurale, totalisant de façon idéale 24 atomes d'oxygène, est $2\left[\left(\mathrm{Na}_{1.906} \mathrm{Ca}_{0.039}\right){ }_{1.945}\left(\mathrm{Ce}_{1.030} \mathrm{La}_{0.621} \mathrm{Nd}_{0.229} \mathrm{Pr}_{0.081}\right.\right.$ $\left.\left.\mathrm{Sm}_{0.014}\right)_{\Sigma 1.975}\left(\mathrm{Ti}_{0.875} \mathrm{Nb}_{0.109}\right)_{\Sigma 0.984} \mathrm{O}_{2} \mathrm{H}_{0.250}\left(\mathrm{Si}_{0.971} \mathrm{O}_{4}\right)\left(\mathrm{C}_{0.989} \mathrm{O}_{3}\right)_{2}\right]$. Nous en avons affiné la structure jusqu'à un résidu $R$ de $2.7 \%$ en utilisant 2827 réflexions uniques. La structure est faite de trois couches distinctes parallèles à (010): (1) un niveau Na-Ti-Si$\mathrm{O}$, (2) un niveau $\mathrm{Ce}-\mathrm{C}-\mathrm{O}$, et (3) un niveau $\mathrm{Na}-\mathrm{O}$. Ces couches sont interliées par des groupes $\left[\mathrm{CO}_{3}\right]^{2-}$ et $\left[\mathrm{SiO}_{4}\right]^{4-}$ indépendants. Des quantités mineures de $\mathrm{OH}$ assurent la neutralité des charges qui résultent des substitutions $\mathrm{Nb} \leftrightarrow \mathrm{Ti}$ et $\mathrm{Ca} \leftrightarrow \mathrm{REE}$.

(Traduit par la Rédaction)

Mots-clés: tundrite-(Ce), structure cristalline, terres rares, composition chimique, spectroscopie infrarouge, hydrogène, mont Saint-Hilaire, Québec.

\& E-mail address: jgrice@mus-nature.ca 


\section{INTRODUCTION}

Tundrite was first described by Semenov (1963) from three nepheline syenite pegmatites on Mt. Nepkha, Lovozero complex, Kola Peninsula, Russia. The mineral was described as being triclinic and having the formula $\mathrm{Ce}_{2} \mathrm{Ti}(\mathrm{Si}, \mathrm{P})(\mathrm{O}, \mathrm{OH})_{7} \bullet 4 \mathrm{H}_{2} \mathrm{O}$. The crystallography, both optical and X-ray, are in good agreement with descriptions of other tundrite-group minerals that have been described subsequently, but the chemical data are in error. Semenov et al. (1967) described another occurrence of tundrite-group minerals from the Ilímaussaq complex, South Greenland. Ceriumdominant members, previously named "tundrite", were renamed tundrite-(Ce), and $\mathrm{Nd}$-dominant compositions were described as the new mineral species tundrite(Nd). The authors recognized the presence of major amounts of sodium by chemical analysis. The formulae were given as $\mathrm{Na}_{2} \mathrm{Ce}_{2}(\mathrm{Ti}, \mathrm{Nb}) \mathrm{SiO}_{8} \bullet 4 \mathrm{H}_{2} \mathrm{O}(Z=2)$ or $\mathrm{Na}_{3} \mathrm{Ce}_{3}(\mathrm{Ti}, \mathrm{Nb})_{2} \mathrm{Si}_{2} \mathrm{O}_{14} \bullet 8 \mathrm{H}_{2} \mathrm{O}(Z=1)$. Not until the work of Shlyukova et al. (1973) was the presence of carbonate discovered in tundrite-group minerals, given the revised formula $(\mathrm{Na}, \mathrm{K})_{3}(\mathrm{REE}, \mathrm{Ca})_{4}(\mathrm{Ti}, \mathrm{Nb})_{2}\left(\mathrm{SiO}_{4}\right)_{2}\left(\mathrm{CO}_{3}\right)_{3} \mathrm{O}_{4}$ $(\mathrm{OH}) \cdot 2 \mathrm{H}_{2} \mathrm{O}$. The proportion of the rare-earth elements was not given, so it is not certain whether this was tundrite-(Ce) or tundrite-(La). This material was good enough for a crystal-structure analysis by Shumyatskaya et al. (1976), which led to the formula $\mathrm{Na}_{2} \mathrm{Ce}_{2} \mathrm{TiO}_{2}$ $\left(\mathrm{SiO}_{4}\right)\left(\mathrm{CO}_{3}\right)_{2}$. This crystal-structure analysis, with a rather large degree of uncertainty, having an $R$ index of $7 \%$, was not supported by chemical analyses, and its variance with the data of Shlyukova et al. (1973) was not explained. A detailed study of tundrite-(Ce) from the Ilímaussaq complex, South Greenland, was published by Karup-Møller (1982), who gave the formula $\mathrm{Na}_{3.17}\left(\mathrm{Ce}_{1.78} \mathrm{Nd}_{0.73}\right.$ $\left.\mathrm{La}_{0.63} \mathrm{Pr}_{0.25} \mathrm{Sm}_{0.12} \mathrm{Gd}_{0.04} \mathrm{Ca}_{0.16}\right)_{\Sigma 3.71}\left(\mathrm{Nb}_{0.31} \mathrm{Ti}_{1.83}\right)_{\Sigma 2.14}$ $\mathrm{O}_{4.25}\left(\mathrm{SiO}_{4}\right)_{2}\left(\mathrm{CO}_{3}\right)_{3.27}$. The disparity in results among these reports warranted a restudy of tundrite-(Ce), especially in view of the availability of newly discovered, well-crystallized material.

\section{OCCURRENCE}

In May, 2006, Dr. R. Peter Richards of Oberlin, Ohio, noted the presence of a mineral, later identified as tundrite-(Ce), in an isolated boulder in Mont SaintHilaire, Quebec. He relayed the information to Willow and Quintin Wight, who located the boulder, in use as a road marker. The boulder, approximately one meter high and one-and-a-half meters long, is a pegmatitic segregation that clearly did not originate within the hornfels unit where it presently rested. Its origin must lie somewhere in the pegmatitic segregation associated with the block of igneous breccia in the higher (southwesterly) portion of the quarry. Externally, the boulder appeared barren of interesting minerals, but a trial blow knocked off a large fragment, revealing a cluster of goldenyellow tundrite-like blades embedded in analcime. The analcime host was like a plug, blocking the entrance to a larger cavity beneath. There was no trace of tundritegroup minerals within the cavity itself. A search of the dislodged material located further fragments of the original portion removed by the hammer blow. Minerals associated with tundrite-(Ce) are aegirine, albite, analcime, an astrophyllite-group mineral, catapleiite, a eudialyte-group mineral, gonnardite, mangan-neptunite, monazite-(Ce), natrolite, quartz, rhodochrosite, sphalerite and vinogradovite.

Material is housed in the collection of the Canadian Museum of Nature, Ottawa under catalogue number CMNMC 85866.

\section{Physical AND Optical Properties}

Tundrite-(Ce) belongs to the triclinic pinacoidal class, $\overline{1}$. The crystals are bladed on $\{010\}$, elongate on [001], up to $9 \mathrm{~mm}$ in length (Fig. 1). The following pinacoid forms were measured and drawn (Fig. 2): $\{100\}$, $\{010\},\{201\}$ and $\{\overline{1} 01\}$. No twinning was observed, and $\{100\}$ faces are heavily striated owing to the $\{010\}$ platy nature of the crystals. The crystals are translucent, pale yellow in color, with a white streak and a vitreous luster. There is no fluorescence with either short-wave or long-wave ultraviolet light. The mineral has an approximate hardness of 3 (Mohs scale), is brittle and splintery, with a perfect $\{010\}$ cleavage. The density, $4.08 \mathrm{~g} / \mathrm{cm}^{3}$, measured by the Berman balance method, agrees well with the calculated density, $4.19 \mathrm{~g} / \mathrm{cm}^{3}$.

Tundrite-(Ce) is biaxial positive, $2 V_{\text {meas }}=84(5)^{\circ}$ with $\beta=1.80$. The dispersion is strong, with $r>v$, and pleochroism is weak, with $Y=$ pale yellow and $Z$ $=$ greenish yellow. The optical orientation is $X=[010]$, $Z \approx \mathbf{c}$.

\section{Chemical Composition}

\section{Electron-microprobe analysis}

Compositions were obtained using a JEOL 733 Superprobe in wavelength-dispersion mode. Operating conditions were $15 \mathrm{kV}, 20 \mathrm{nA}$ with a probe diameter of $10 \mu \mathrm{m}$. Counts were collected for $25 \mathrm{~s}$ or until $0.50 \%$ precision was attained. In spite of the high sodium content of this mineral, it proved to be very resistant to beam damage. Monitoring of $\mathrm{NaK \alpha}$ counts over a period of several minutes (longer than the total duration of the analysis) showed no detectable change in count rate. The following X-ray lines and standards were used for analysis: albite $(\mathrm{Na} K \alpha, \mathrm{Si} K \alpha)$, fersmite $(\mathrm{Ca} K \alpha)$, rutile (TiKo), manganocolumbite $(\mathrm{Nb} L \alpha)$, $\mathrm{NiTa}_{2} \mathrm{O}_{6}(\mathrm{Ta} L \alpha)$ and synthetic REE phosphates for $(\mathrm{La} L \alpha, \operatorname{Ce} L \alpha, \operatorname{Pr} L \alpha, \operatorname{Nd} L \alpha, \operatorname{Sm} L \alpha$ ). Raw data were corrected using a PAP correction routine (Pouchou \& 

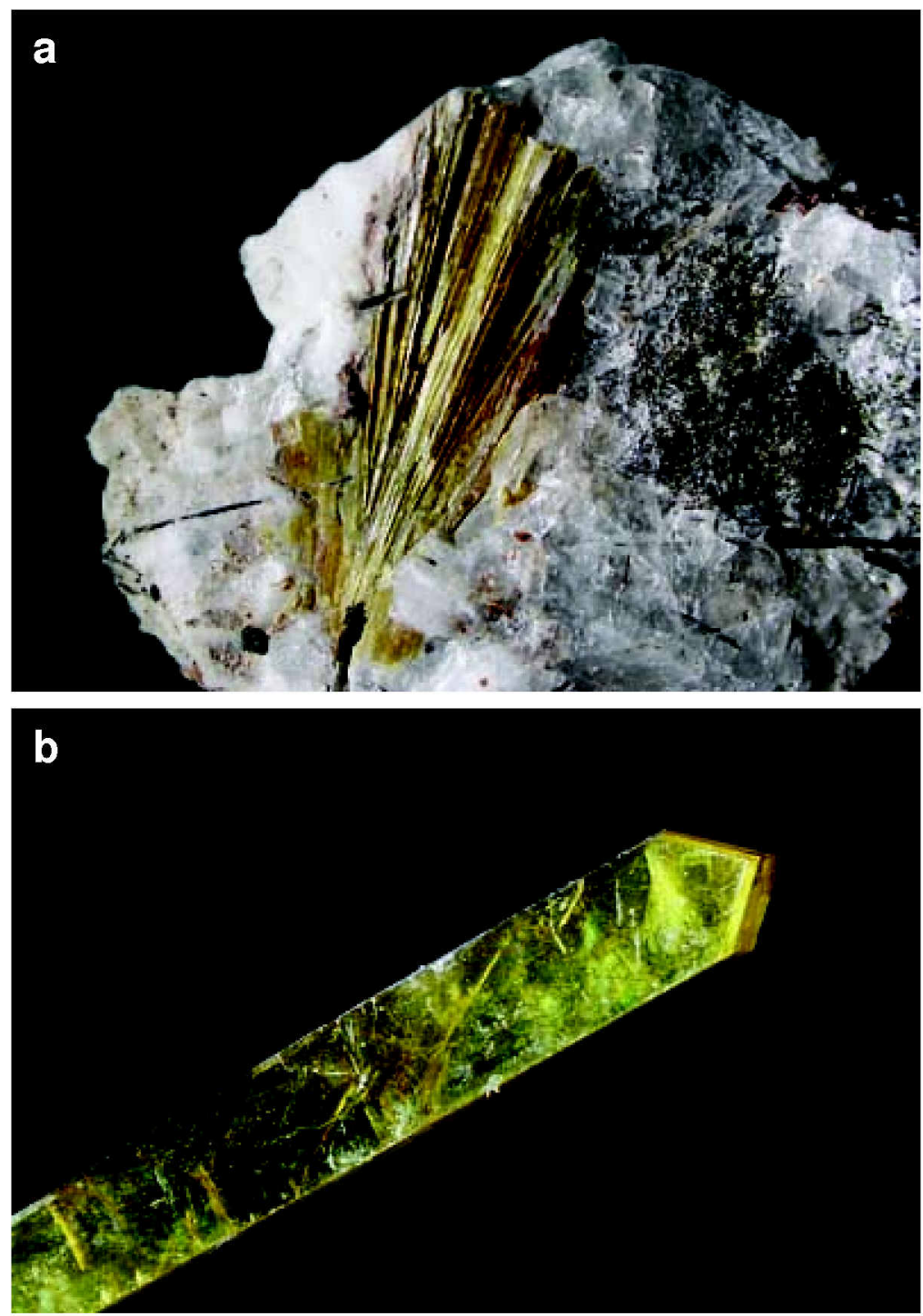

FIG. 1. Tundrite-(Ce) from Mont Saint-Hilaire, Quebec. (a) Radiating group of crystals $25 \mathrm{~mm}$ long (photo: Willow Wight). (b) Prismatic crystal $7 \mathrm{~mm}$ long in photograph (photo: Quintin Wight).

Pichoir 1984) as part of the XMQANT package (pers. commun., C. Davidson, CSIRO) . In total, 20 analyses were performed on seven separate grains. The amounts of $\mathrm{CO}_{2}$ and $\mathrm{H}_{2} \mathrm{O}$ were determined by thermogravimetric analysis (described below). The analytical results are summarized in Table 1. The empirical formula, based on 24 atoms of oxygen as determined by crystal-structure analysis, is: $2\left[\left(\mathrm{Na}_{1.906} \mathrm{Ca}_{0.039}\right)_{\Sigma 1.945}\left(\mathrm{Ce}_{1.030} \mathrm{La}_{0.621}\right.\right.$ $\left.\mathrm{Nd}_{0.229} \mathrm{Pr}_{0.081} \mathrm{Sm}_{0.014}\right)_{\Sigma 1.975}\left(\mathrm{Ti}_{0.875} \mathrm{Nb}_{0.109}\right)_{\Sigma 0.984} \mathrm{O}_{2} \mathrm{H}_{0.250}$ $\left.\left(\mathrm{Si}_{0.971} \mathrm{O}_{4}\right)\left(\mathrm{C}_{0.989} \mathrm{O}_{3}\right)_{2}\right]$.
Examination of the data shows a limited extent of substitution of $\mathrm{Nb}$ for Ti (Fig. 3).

\section{Thermogravimetric and differential scanning calorimetry analysis}

Thermogravimetric (TGA) - differential scanning calorimetry (DSC) analysis was made with a TA Instruments Q600 SDT instrument. A $10.9120 \mathrm{mg}$ powdered sample was heated from room temperature to $800^{\circ} \mathrm{C}$ at 
$10^{\circ} \mathrm{C}$ min $^{-1}$ with $\mathrm{N}_{2}$ as a purge gas. The weight losses occurred in two steps: the first loss, a small endothermic peak centered at $50^{\circ} \mathrm{C}$, is $0.03887 \mathrm{mg}(0.36 \mathrm{wt} . \%)$

TABLE 1. TUNDRITE: CHEMICAL COMPOSITION

\begin{tabular}{|c|c|c|c|c|c|c|c|}
\hline & $\begin{array}{l}\text { Average } \\
(n=20)\end{array}$ & $M^{\prime} L^{+}$ & Min & Max & Range & $\begin{array}{l}\text { Standard } \\
\text { deviation }\end{array}$ & Theoretical \\
\hline $\mathrm{Na}_{2} \mathrm{O}$ wt.\% & 9.44 & 0.06 & 9.07 & 9.66 & 0.59 & 0.16 & 10.03 \\
\hline $\mathrm{CaO}$ & 0.34 & 0.21 & 0.16 & 0.42 & 0.26 & 0.07 & \\
\hline $\mathrm{La}_{2} \mathrm{O}_{3}$ & 16.16 & 0.20 & 15.42 & 17.95 & 2.53 & 0.63 & \\
\hline $\mathrm{Ce}_{2} \mathrm{O}_{3}$ & 27.03 & 0.33 & 25.41 & 28.56 & 3.15 & 0.62 & 53.10 \\
\hline $\mathrm{Pr}_{2} \mathrm{O}_{3}$ & 2.13 & 0.30 & 1.72 & 2.38 & 0.66 & 0.17 & \\
\hline $\mathrm{Nd}_{2} \mathrm{O}_{3}$ & 6.17 & 0.38 & 5.61 & 6.58 & 0.97 & 0.23 & \\
\hline $\mathrm{Sm}_{2} \mathrm{O}_{3}$ & 0.39 & 0.35 & 0.18 & 0.73 & 0.55 & 0.14 & \\
\hline $\mathrm{TiO}_{2}$ & 11.17 & 0.14 & 10.73 & 11.93 & 1.20 & 0.34 & 12.92 \\
\hline $\mathrm{Nb}_{2} \mathrm{O}_{5}$ & 2.31 & 0.08 & 1.14 & 3.11 & 1.97 & 0.50 & \\
\hline $\mathrm{Ta}_{2} \mathrm{O}_{5}^{\circ}$ & 0.07 & 0.16 & 0.00 & 0.15 & 0.15 & 0.04 & \\
\hline $\mathrm{SiO}_{2}$ & 9.32 & 0.03 & 9.10 & 9.54 & 0.44 & 0.10 & 9.72 \\
\hline $\mathrm{CO}_{2}{ }^{*}$ & 13.91 & & & & & & 14.24 \\
\hline $\mathrm{H}_{2} \mathrm{O}^{*}$ & 0.36 & & & & & & \\
\hline Fotal & 98.80 & & 97.43 & 100.17 & 2.74 & 0.79 & 100.00 \\
\hline Na apfu & 3.812 & & 3.666 & 3.909 & 0.243 & 0.06 & 4 \\
\hline $\mathrm{Ca}$ & 0.077 & & 0.036 & 0.094 & 0.058 & 0.02 & \\
\hline La & 1.241 & & 1.182 & 1.367 & 0.185 & 0.05 & \\
\hline $\mathrm{Ce}$ & 2.060 & & 1.918 & 2.169 & 0.251 & 0.05 & 4 \\
\hline $\operatorname{Pr}$ & 0.362 & & 0.131 & 0.180 & 0.049 & 0.01 & \\
\hline Nd & 0.458 & & 0.422 & 0.488 & 0.066 & 0.02 & \\
\hline $\mathrm{Sm}$ & 0.028 & & 0.013 & 0.052 & 0.039 & 0.01 & \\
\hline Ti & 1.750 & & 1.679 & 1.862 & 0.183 & 0.05 & 2 \\
\hline Nb & 0.218 & & 0.107 & 0.290 & 0.183 & 0.05 & \\
\hline Ta & 0.004 & & 0.000 & 0.009 & 0.009 & 0.01 & \\
\hline $\mathrm{Si}$ & 1.941 & & 1.902 & $\$ .972$ & 0.070 & 0.02 & 2 \\
\hline c & 3.956 & & & & & & \\
\hline H & 0.501 & & & & & & \\
\hline$\sum$ cations & 16.205 & & & & & & 16 \\
\hline
\end{tabular}

$\uparrow$ minimum level of detection based on counting statistics.

${ }^{*} \mathrm{CO}_{2}$ and $\mathrm{H}_{2} \mathrm{O}$ from TGA analysis. The proportion of cations is calculated on the basis of 24 atoms of oxygen per formula unit (apfu). and the second loss, a large sharp endothermic peak centered at $713^{\circ} \mathrm{C}$, is $9.355 \mathrm{mg}(13.91 \mathrm{wt} \%)$. The first loss is attributed to $\mathrm{H}_{2} \mathrm{O}$, whereas the second loss is essentially $\mathrm{CO}_{2}$.

\section{Infrared analysis}

The infrared spectrum of tundrite-(Ce) (Fig. 4) was obtained using a Bomen Michelson MB-120 Fouriertransform infrared spectrometer with a diamond-anvil cell microsampling device. The spectra are well resolved and provide a clear example of the vibration modes for isolated $\left[\mathrm{CO}_{3}\right]^{2-}$ and $\left[\mathrm{SiO}_{4}\right]^{4-}$ groups. The broad ( 3600 to $2700 \mathrm{~cm}^{-1}$ ), low peak centered in the $3401 \mathrm{~cm}^{-1}$ region is the $\mathrm{O}-\mathrm{H}$ or $\mathrm{H}-\mathrm{O}-\mathrm{H}$ stretch frequency, indicating the presence of an $[\mathrm{OH}]^{-}$or an $\left[\mathrm{H}_{2} \mathrm{O}\right]$ group. The $\mathrm{H}-\mathrm{O}-\mathrm{H}$ bend region (1690-1590 $\mathrm{cm}^{-1}$ ) does not lead to a clear interpretation of spectral peaks, but from crystal-structure analysis, it is evidently all $[\mathrm{OH}]$. Comparing the remaining complex part of the spectrum to spectra given in Farmer (1974), the following regions of frequency are assigned modes: the two $\left[\mathrm{CO}_{3}\right]^{2-}$ groups are both in general atom positions giving rise to several sharp spectral peaks $\left(\mathrm{cm}^{-1}\right): \nu_{2}$ $+v_{6}$ : asymmetric stretching in additive combination, 1784 and $1759 ; v_{3}$ : asymmetric stretching, 1535 (plus shoulder), 1435 and $1381 ; v_{1}$ symmetric stretching, 1081 and 1067; $v_{4}$; in-plane bending 719, 704, 694 and 651 . The single $\left[\mathrm{SiO}_{4}\right]^{4-}$ group is also in a general atom position: $v_{1}+\mu_{3}$ : symmetric stretching, 949, 897 and $851 ; v_{2}+v_{4}$ : in-plane and out-of-plane bending, 555,501 and 460 .
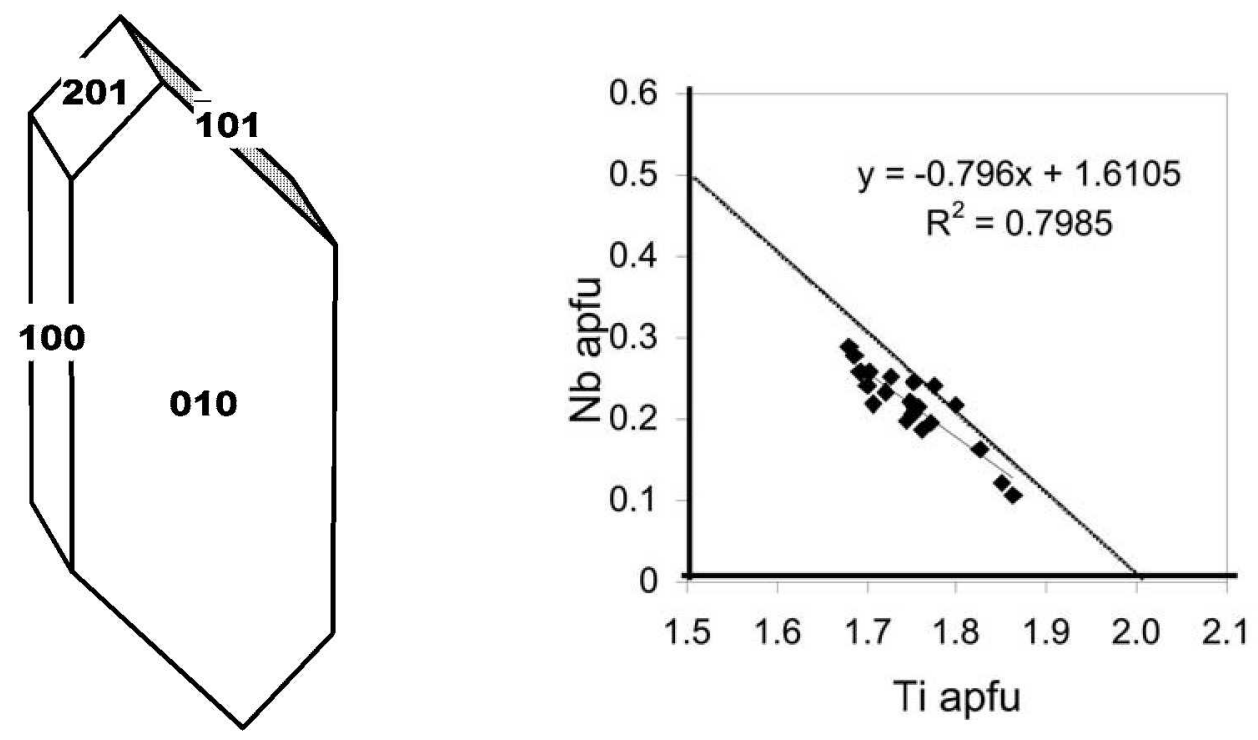

FIG. 2. Crystal drawing of tundrite.

FIG. 3. Plot of Nb versus $\mathrm{Ti}$ in tundrite-(Ce) for all analytical datasets. Dashed line has a slope of minus one. 


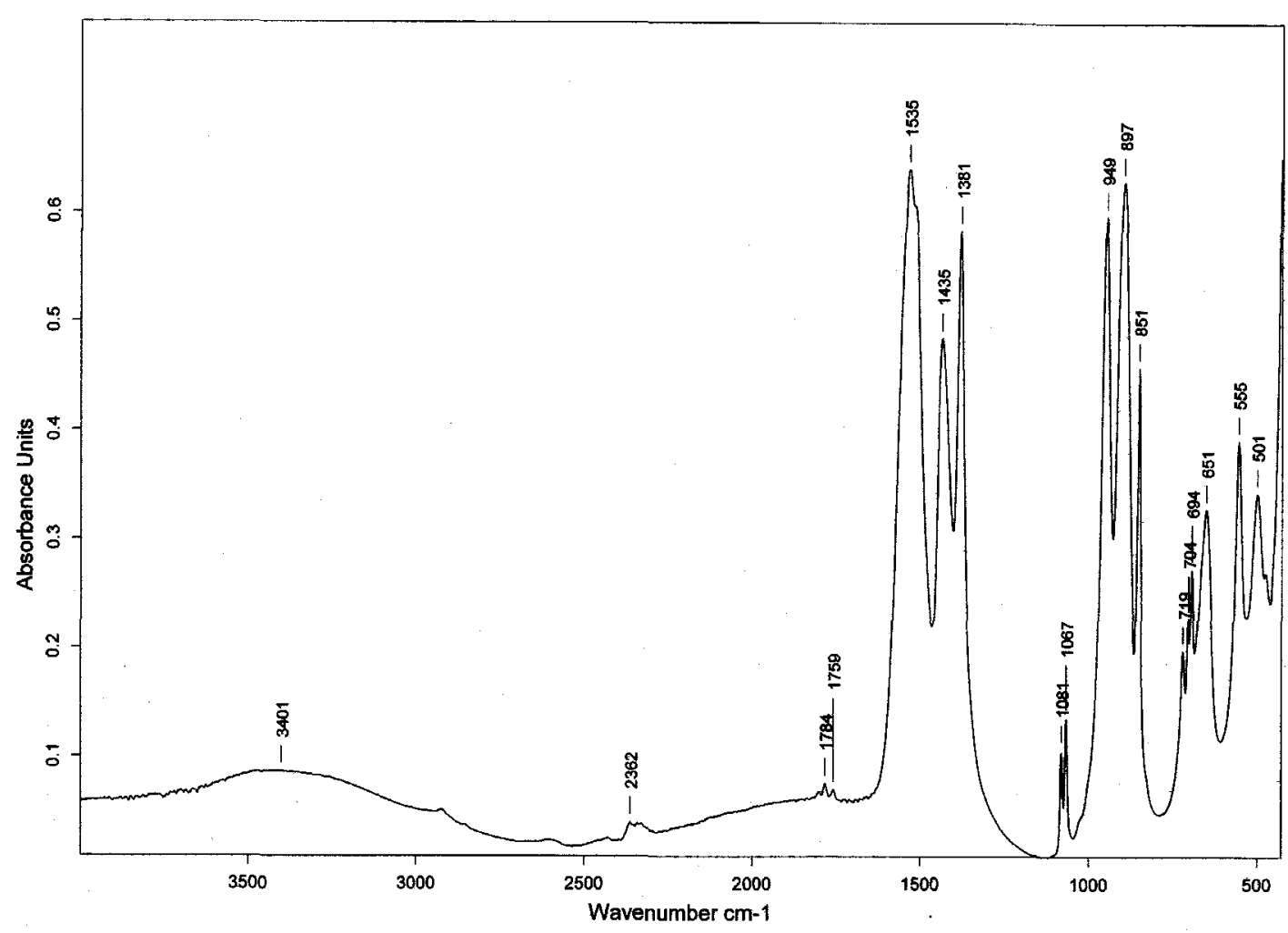

FIG. 4. Infrared absorption spectra for tundrite-(Ce).

\section{X-Ray CRYSTallography AND Crystal-Structure Determination}

X-ray powder-diffraction data were collected with a Bruker AXS Discover 8 microdiffractometer using Hi-Star 2-D area detector operated with a GADDS system, $\mathrm{CuK \alpha} \alpha_{1}$ radiation at $40 \mathrm{kV}, 40 \mathrm{~mA}$, with a sample-to-detector distance of $12 \mathrm{~cm}$ (Table 2). The instrument was calibrated with synthetic corundum using a new statistical method of calibration. This method is based on a statistical comparison of changes in $\Delta 2 \theta$ error when adjusting the different calibration parameters, consequently allowing an optimization of these parameter values for a minimal $\Delta 2 \theta$ error. Indexing of the measured pattern was achieved with the intensities from a powder pattern calculated using atom coordinates determined in the crystal-structure analysis. Diffuse non-diagnostic diffraction was observed in the 75 to $100^{\circ}$ range as broad bulging peaks, therefore not useable for cell-refinement data. Differences between measured versus calculated intensities are consistent with what is expected in a triclinic structure, where many $h k l$ planes are contributing to the intensity of one measured peak.
X-ray precession photographs were used to select a single crystal of tundrite-(Ce). Trimming a cleavage fragment of this mineral was found to be difficult owing to its splintery nature, which gives rise to adhering satellite fragments producing streaky X-ray-diffraction reflections. The single crystal chosen for the collection of intensity data measured $0.12 \times 0.12 \times 0.30 \mathrm{~mm}$. Intensity data were collected on a fully automated Bruker $P 4$ four-circle diffractometer operated at 50 $\mathrm{kV}, 40 \mathrm{~mA}$, with graphite-monochromated $\mathrm{MoK \alpha}$ radiation and a $4 \mathrm{~K}$ APEX CCD detector mounted at a distance of $6 \mathrm{~cm}$ from the crystal. Integrated intensities were collected up to $2 \theta=60^{\circ}$, using $10 \mathrm{~s}$ frame counts and a frame width of $0.25^{\circ}$. Data pertinent to the intensity-data collection are given in Table 3 . The unit-cell parameters for the single crystal were refined using 5523 indexed reflections.

Reduction of the intensity data, structure determination and structure refinement were done with the SHELXTL (Sheldrick 1990) package of computer programs. Data reduction included corrections for background, scaling and Lorentz-polarization factors. An empirical absorption-correction (SADABS, Sheldrick 1998 ) was applied. The merging $R_{\text {(int) }}$ for the dataset 
TABLE 2. TUNDRITE: X-RAY POWDER-DIFFRACTION DATA

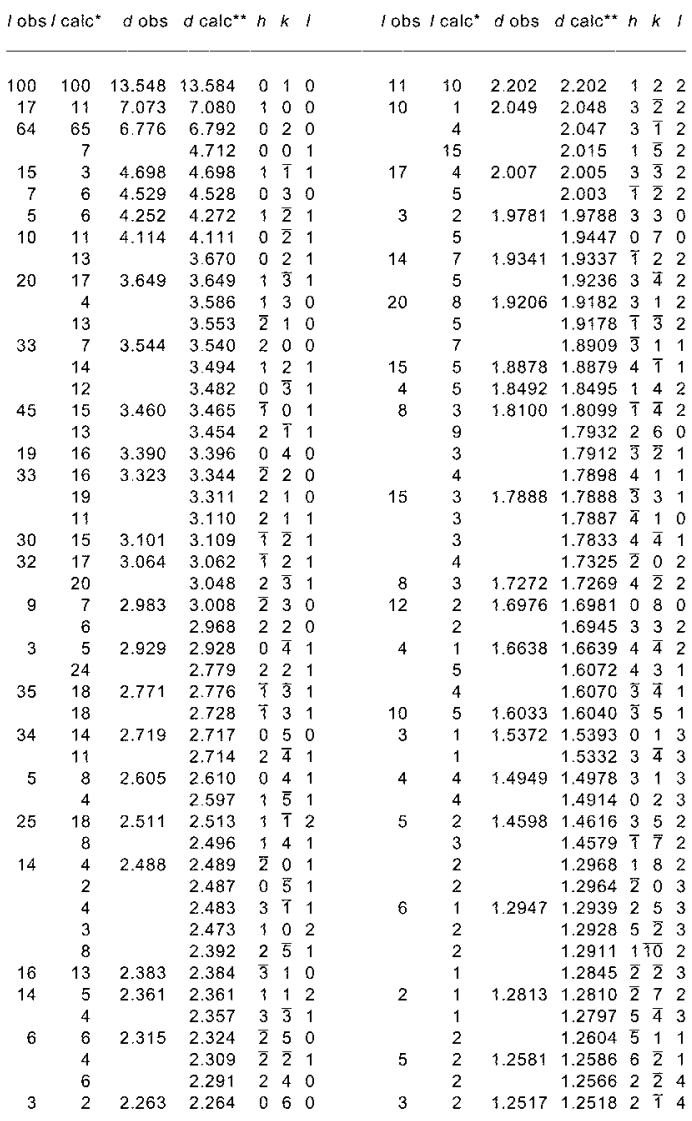

* calculated from crystai-structure determination

** calculated from XRPD cell refinement with a $7.577(2), b 13.944(3), c 5.026(1) A$, $\alpha 100.08(2), \beta 70.80(2)$, y $101.07(2)^{\circ}, V=488.6(1) \mathrm{A}^{3}$

(9606 reflections) decreased from 0.030 before the absorption correction to 0.022 after the absorption correction. Assigning phases to a set of normalized structure-factors gave a mean value $\left|E^{2}-1\right|$ of 0.994 , suggesting the centrosymmetric space-group $P \overline{1}$. The starting positions of the atoms are those of Shumyatskaya et al. (1976). In the last stages of refinement, there was a marked residual of electrons of $3.0 \mathrm{e}^{-} / \AA^{3}$, evident in the difference-Fourier map in the region of the $\left[\mathrm{SiO}_{4}\right]$ tetrahedron, $\left[\mathrm{CO}_{3}\right]$ triangle and $\left[\mathrm{Ce} 1 \mathrm{O}_{9}\right]$ polyhedron. There was an additional weak residual associated with the $\left[\mathrm{Ce} 2 \mathrm{O}_{9}\right]$ polyhedron, but as it was only at the level of resolution of the background in the difference Fourier map, it was not included in the residual refinement. The larger residual peak was allowed to refine as an $\mathrm{O}$ atom $(O H 13)$ with a variable site-occupancy factor (sof), which gave a sof $=0.11(1)$. In addition, two very weak residuals were found associated with $O 5$ and $O 6$ atoms at a distance of approximately $1 \AA$. These were refined as $\mathrm{H}$ atoms. In the final least-squares refinement, all atom positions were refined with anisotropic displacement-factors except for the low-electron sites $O H 13$, $H 5$, and $H 6$. The weighting scheme is inversely proportional to $\sigma^{2}(F)$. The addition of an isotropic extinctioncorrection did not improve the refinement. The final positional and anisotropic displacement-parameters are given in Table 4, and selected bond-lengths and angles, in Table 5. Tables listing the observed and calculated structure-factors may be obtained from the Depository of Unpublished Data on the MAC web site [document: Tundrite CM46_413].

\section{Description of tHe Structure}

In the structure of tundrite-(Ce), there are two REE sites, both with nine-fold coordination. Karup-Møller (1982) suggested, on the basis of results of his chemical analyses, that one site is Ce-dominant, and the other contains the remaining REE cations, $\mathrm{La}, \mathrm{Nd}$, Pr and $\mathrm{Sm}$. In this structure refinement, there is supporting evidence, although not irrefutable, for this pattern of order of REE atoms. The indications for this pattern are: (a) the site occupancy of $\mathrm{Ce} 1$ refines to almost pure $\mathrm{Ce}, 56.3(2) e^{-}$, whereas $\mathrm{Ce} 2$ refines to $55.7(2)$ $e^{-}$, which compares well with the number of electrons based on the sum of the remaining electrons for $\mathrm{La}, \mathrm{Pr}$, $\mathrm{Nd}$ and $\mathrm{Sm}$ in the chemical analyses, $54.8 e^{-}$; (b) the slight increase in average bond-length from $\langle\mathrm{Cel}-\mathrm{O}\rangle$ $=2.572 \AA$ to $\langle C e 2-\mathrm{O}\rangle=2.590 \AA$ is consistent with increases in atomic radii within the $\mathrm{REE}$ from $\mathrm{Ce}$ to La. The three $\mathrm{Na}$ sites have [6]-coordinated polyhedra, with $N a 1$ and $N a 3$ having almost regular octahedral coordination with $\mathrm{O}$ and a refined site-occupancy of $11 e^{-}$, whereas the coordination of $\mathrm{Na} 2$ with $\mathrm{O}$ may be described as a bifurcated tetragonal pyramid. This novel $\mathrm{Na} 2$ site has slightly higher site-occupancy, 11.9(1) $e^{-}$, indicating that it incorporates heavier atoms such as $\mathrm{Ca}$ or the REE. The Ti site has a regular octahedral coordination, and the site-occupancy refinement, 23.8(2) $e^{-}$, agrees very well with the $\mathrm{Ti}$ and $\mathrm{Nb}$ content of the site, which has $23.9 e^{-}$. The single $S i$ site and the two $C$ sites have regular tetrahedral and triangular coordination, respectively.

TABLE 3. TUNDRITE: DATA COLLECTION AND STRUCTURE-REFINEMENT INFORMATION

\begin{tabular}{lclc}
\hline Space group & \multicolumn{1}{c}{$P^{\overline{1}}$} & Measured reflections & 11046 \\
$a(A)$ & $7.5760(4)$ & Unique refiections & 2827 \\
$b(A)$ & $13.9252(7)$ & Observed reflections $[1>4 \sigma(F)]$ & 2803 \\
$c(A)$ & $5.0290(2)$ & $R($ int $)(\%)$ & 1.4 \\
$\left.\alpha()^{\circ}\right)$ & $99.981(1)$ & Goodness of tit on $F^{2}$ & 1.22 \\
$\beta\left({ }^{\circ}\right)$ & $70.791(1)$ & $R$ index $(\%)$ for all data & 2.7 \\
$Y\left({ }^{\circ}\right)$ & $100.947(1)$ & $W R^{2}(\%)$ for atl data & 7.3 \\
$V\left(A^{3}\right)$ & $488.37(7)$ & Refinement by full-matrix least squares on $F^{2}$
\end{tabular}

Ideal unit-cell contents: $2\left[\mathrm{Na}_{2} \mathrm{Ce}_{2} \mathrm{TiO}_{2}\left(\mathrm{SiO}_{4}\right)\left(\mathrm{CO}_{3}\right)_{2}\right]$ $\mu=11.2 \mathrm{~mm}^{-1}$ 
TABLE 4. TUNDRITE: ATOM COORDINATES AND DISPLACEMENT PARAMETERS $\left(\AA^{2}\right)$

\begin{tabular}{|c|c|c|c|c|c|c|c|c|c|c|}
\hline Site & $x$ & $y$ & $z$ & $U_{11}$ & $U_{22}$ & $U_{33}$ & $U_{23}$ & $U_{13}$ & $U_{12}$ & $U_{\text {eq }}$ \\
\hline $\mathrm{Ce} 1$ & $0.6573(3)$ & $0.7797(2)$ & $0.5952(4)$ & $0.0104(1)$ & $0.0119(1)$ & $0.0077(1)$ & $0.00224(7)$ & $-0.00438(8)$ & $0.00036(8)$ & $0.00968(7)$ \\
\hline $\mathrm{Ce} 2$ & $0.2195(3)$ & $0.77840(2)$ & $0.3119(4)$ & $0.0112(1)$ & $0.0142(1)$ & $0.0062(1)$ & $0.00148(8)$ & $-0.00127(8)$ & $0.00402(8)$ & $0.01052(7)$ \\
\hline $\mathrm{Na} 1$ & 0 & 0 & $1 / 2$ & $0.039(2)$ & $0.012(1)$ & $0.014(1)$ & $-0.0022(9)$ & $0.011(1)$ & $0.001(1)$ & $0.0212(6)$ \\
\hline $\mathrm{Na} 2$ & $0.1375(3)$ & $0.4719(1)$ & $0.1759(4)$ & $0.030(1)$ & $0.032(1)$ & $0.027(1)$ & $-0.0001(7)$ & $-0.0083(7)$ & $0.0068(7)$ & $0.0299(6)$ \\
\hline $\mathrm{Na} 3$ & $1 / 2$ & $1 / 2$ & $1 / 2$ & $0.049(2)$ & $0.019(1)$ & $0.014(1)$ & $0.003(1)$ & $-0.012(1)$ & $-0.010(1)$ & $0.0286(7)$ \\
\hline $\mathrm{Ti}$ & $0.60840(9)$ & $0.99963(5)$ & $0.1957(1)$ & $0.0130(3)$ & $0.0133(3)$ & $0.0097(3)$ & $0.0008(2)$ & $-0.0037(2)$ & $0.0020(2)$ & $0.0120(1)$ \\
\hline $\mathrm{Si}$ & $0.9622(2)$ & $0.85797(8)$ & $0.9129(2)$ & $0.0096(6)$ & $0.0114(4)$ & $0.0051(4)$ & $0.0008(3)$ & $-0.0029(3)$ & $0.0018(4)$ & $0.0085(2)$ \\
\hline$C 1$ & $0.7921(6)$ & $0.3546(3)$ & $0.2374(9)$ & $0.015(2)$ & $0.014(2)$ & $0.013(2)$ & $0.001(1)$ & $-0.004(1)$ & $0.005(1)$ & $0.0136(7)$ \\
\hline $\mathrm{C} 2$ & $0.6011(6)$ & $0.652(3)$ & $0.0601(8)$ & $0.010(2)$ & $0.016(2)$ & $0.010(2)$ & $0.003(1)$ & $-0.001(1)$ & $0.001(1)$ & $0.0125(7)$ \\
\hline 01 & $0.9339(4)$ & $0.7555(2)$ & $0.7084(6)$ & $0.009(1)$ & $0.011(1)$ & $0.009(1)$ & $0.0012(9)$ & $-0.0034(9)$ & $0.0013(9)$ & $0.0097(5)$ \\
\hline $\mathrm{O} 2$ & $0.7939(4)$ & $0.9173(2)$ & $0.9117(6)$ & $0.012(1)$ & $0.014(1)$ & $0.007(1)$ & $-0.0007(9)$ & $-0.003(9)$ & $0.004(1)$ & $0.0109(5)$ \\
\hline 03 & $0.1629(4)$ & $0.9161(2)$ & $0.7260(6)$ & $0.009(1)$ & $0.013(1)$ & $0.009(1)$ & $0.0021(9)$ & $-0.0030(9)$ & $-0.0002(9)$ & $0.0107(5)$ \\
\hline 04 & $0.9575(4)$ & $0.8437(2)$ & $0.2269(6)$ & $0.013(1)$ & $0.015(1)$ & $0.007(1)$ & $0.0030(9)$ & $-0.0026(9)$ & $0.003(1)$ & $0.0115(5)$ \\
\hline 05 & $0.4070(4)$ & $0.9179(2)$ & $0.0663(6)$ & $0.012(1)$ & $0.012(1)$ & $0.008(1)$ & $0.0022(9)$ & $-0.0040(9)$ & $0.000(1)$ & $0.0110(5)$ \\
\hline 06 & $0.5507(4)$ & $0.9191(2)$ & $0.4970(6)$ & $0.015(1)$ & $0.011(1)$ & $0.007(1)$ & $0.0025(9)$ & $-0.001(1)$ & $0.005(1)$ & $0.0115(5)$ \\
\hline 07 & $0.8718(5)$ & $0.3811(2)$ & $0.9889(7)$ & $0.027(2)$ & $0.019(1)$ & $0.017(1)$ & $0.009(1)$ & $-0.007(1)$ & $-0.002(1)$ & $0.0212(7)$ \\
\hline 08 & $0.8080(5)$ & $0.4068(3)$ & $0.4629(8)$ & $0.025(2)$ & $0.028(2)$ & $0.021(2)$ & $-0.010(1)$ & $-0.009(1)$ & $-0.001(1)$ & $0.0265(8)$ \\
\hline 09 & $0.3328(5)$ & $0.3774(2)$ & $0.7677(7)$ & $0.028(2)$ & $0.016(1)$ & $0.013(1)$ & $0.004(1)$ & $-0.009(1)$ & $0.003(1)$ & $0.0178(6)$ \\
\hline 010 & $0.4023(5)$ & $0.3939(2)$ & $0.1762(7)$ & $0.026(2)$ & $0.020(1)$ & $0.014(1)$ & $-0.003(1)$ & $-0.011(1)$ & $0.003(1)$ & $0.0195(6)$ \\
\hline 011 & $0.3072(4)$ & $0.7334(2)$ & $0.7463(6)$ & $0.014(1)$ & $0.017(1)$ & $0.012(1)$ & $0.003(1)$ & $-0.006(1)$ & $-0.001(1)$ & $0.0143(5)$ \\
\hline 012 & $0.5462(4)$ & $0.7392(2)$ & $0.1337(6)$ & $0.014(1)$ & $0.014(1)$ & $0.011(1)$ & $0.000(1)$ & $-0.003(1)$ & $0.004(1)$ & $0.0130(5)$ \\
\hline $\mathrm{OH} 13$ & $0.779(6)$ & $0.781(3)$ & $0.033(7)$ & 0.03 & & & & & & \\
\hline H5 & $0.27(2)$ & $0.90(2)$ & $0.19(4)$ & 0.03 & & & & & & \\
\hline$H 6$ & $0.53(3)$ & $0.86(1)$ & $0.65(3)$ & 0.03 & & & & & & \\
\hline
\end{tabular}

TABLE 5. TUNDRITE: SELECTED INTERATOMIC DISTANCES (A) AND ANGLES $\left({ }^{\circ}\right)$

\begin{tabular}{|c|c|c|c|c|c|c|c|}
\hline $\mathrm{Ce} 1.06$ & $2.420(3)$ & $\mathrm{Ce} 2.01$ & $2.424(3)$ & $\mathrm{Si}-\mathrm{O} 4$ & $1.613(3)$ & O4-Si-O 1 & $114.6(2)$ \\
\hline $\mathrm{Ce} 1-\mathrm{O} 1$ & $2.439(3)$ & $\mathrm{Ce} 2-\mathrm{O} 5$ & $2.439(3)$ & Si-01 & $1.631(3)$ & O4-Si-O3 & $114.2(2)$ \\
\hline Ce1-011 & $2.495(3)$ & $\mathrm{Ce} 2-\mathrm{O} 12$ & $2.472(3)$ & $\mathrm{Si}-\mathrm{O} 3$ & $1.646(3)$ & O4-Si-O2 & $113.5(2)$ \\
\hline $\mathrm{Ce} 1-\mathrm{O} 4$ & $2.535(3)$ & $\mathrm{Ce} 2-\mathrm{O} 4$ & $2.516(3)$ & $\mathrm{Si}-\mathrm{O} 2$ & $3.648(3)$ & $01-\mathrm{Si}-\mathrm{O} 3$ & $103.0(2)$ \\
\hline $\mathrm{Ce} 1-\mathrm{O} 2$ & $2.559(3)$ & $\mathrm{Ce} 2-\mathrm{O} 3$ & $2.557(3)$ & $\langle\mathrm{Si}-\mathrm{O}\rangle$ & $(1.635)$ & O1-Si-O2 & $103.6(2)$ \\
\hline Ce1-09 & $2.591(3)$ & $\mathrm{Ce} 2 . \mathrm{O} 7$ & $2.577(4)$ & & & $\mathrm{O} 3-\mathrm{Si}-\mathrm{O} 2$ & $106.7(2)$ \\
\hline Ce1-012 & $2.658(3)$ & Ce2-011 & $2.682(3)$ & & & $(\mathrm{O}-\mathrm{Si}-\mathrm{O}\rangle$ & $\langle 109.3\rangle^{\prime}$ \\
\hline Ce1-012* & $2.686(3)$ & Ce2-O11* & $2.688(3)$ & $\mathrm{OH} 13-\mathrm{Ce} 1$ & $2.65(3)$ & & \\
\hline Ce1-010 & $2.755(4)$ & $\mathrm{Ce} 2-08$ & $2.939(4)$ & $\mathrm{OH} 13^{*}-\mathrm{Ce} 1$ & $2.67(3)$ & & \\
\hline \multirow{2}{*}{$\langle\mathrm{Ce} 1-\mathrm{O}\rangle$} & $\langle 2.572\rangle$ & $\langle\mathrm{Ce} 2-\mathrm{O}\rangle$ & $\langle 2.590\rangle$ & O5-H5 & 1.17 & & \\
\hline & & & & O6-H6 & 1.06 & & \\
\hline $\mathrm{Na1}-\mathrm{O} 4 \times 2$ & $2.391(3)$ & $\mathrm{Na2-O8}$ & $2.343(4)$ & $\mathrm{Na3}-\mathrm{O} 10 \times 2$ & $2.219(3)$ & Ti-06 & $1.926(3)$ \\
\hline $\mathrm{Na} 1-\mathrm{O} 2 \times 2$ & $2.463(3)$ & $\mathrm{Na} 2-\mathrm{O} 7$ & $2.358(4)$ & $\mathrm{Na3}-\mathrm{O} 9 \times 2$ & $2.277(3)$ & Ti-05 & $1.935(3)$ \\
\hline $\mathrm{Na1} . \mathrm{O} 3 \times 2$ & $2.472(3)$ & $\mathrm{Na} 2-\mathrm{Og}$ & $2.437(4)$ & $\mathrm{Na3} .08 \times 2$ & $2.819(3)$ & $T i=05^{*}$ & $1.945(3)$ \\
\hline \multirow[t]{4}{*}{$\langle\mathrm{Nat}-\mathrm{O}\rangle$} & $\langle 2.443\rangle$ & $\mathrm{Na} 2-010$ & $2.457(4)$ & $\langle\mathrm{Na3}-\mathrm{O}\rangle$ & $(2.440)$ & Ti-O6* & $1.951(3)$ \\
\hline & & $\mathrm{Na} 2-\mathrm{O} 8^{*}$ & $2.522(4)$ & & & Ti-02 & $2.013(3)$ \\
\hline & & $\mathrm{Na} 2 . \mathrm{O}^{*}$ & $2.530(4)$ & & & $\mathrm{Tin} 03$ & $2.013(3)$ \\
\hline & & $\langle\mathrm{Na} 2-\mathrm{O}\rangle$ & $\langle 2.442\rangle$ & & & $\langle\mathrm{T} i-\mathrm{O}\rangle$ & $\langle 1.965\rangle$ \\
\hline $\mathrm{C} 1.08$ & $1.264(5)$ & $\mathrm{O} 8 . \mathrm{C} 1-\mathrm{O} 7$ & $124.1(4)$ & $\mathrm{C} 2-\mathrm{O} 10$ & $1.255(5)$ & $010-C 1.09$ & $124.2(4)$ \\
\hline $\mathrm{C} 1-07$ & $1.281(5)$ & O8-C1-011 & $118.9(4)$ & $\mathrm{C} 2-\mathrm{Og}$ & $1.287(5)$ & O10-C1-012 & $2119.2(4)$ \\
\hline C1-011 & $1.311(5)$ & O7-C1-011 & $116.9(4)$ & $\mathrm{C} 2-012$ & $1.310(5)$ & $\mathrm{O} 9-\mathrm{C} 2-\mathrm{O} 12$ & $116.4(4)$ \\
\hline$\langle\mathrm{C} 1-\mathrm{O}\rangle$ & $\langle 1.287\rangle$ & $\{\mathrm{O}-\mathrm{C} 1-\mathrm{O}\rangle$ & $\langle 120.0\rangle$ & $\langle\mathrm{C} 2-\mathrm{O}\rangle$ & $(1.284)$ & $\langle\mathrm{O} . \mathrm{C} 2 . \mathrm{O}\rangle$ & $\langle 119.9\rangle$ \\
\hline
\end{tabular}

Anion $O H 13$ refined to $0.11(1) \times 2$ (site multiplicity) for a total of 0.22 oxygen atoms per unit cell. This corresponds to $0.32 \mathrm{wt} . \% \mathrm{H}_{2} \mathrm{O}$, which agrees well with that measured by TGA, 0.36 wt. $\% \mathrm{H}_{2} \mathrm{O}$. Figure 5 shows the location of $\mathrm{OH} 13$, placed approximately at an equal spacing between the base of the independent $\left[\mathrm{SiO}_{4}\right]$ tetrahedron and the $\left[\mathrm{CO}_{3}\right]$ triangle. Anion $O H 13$ and its symmetry equivalent $O H 13^{*}$ are bonded to $\mathrm{Cel}$ at 2.65 and $2.67 \AA$, respectively. 

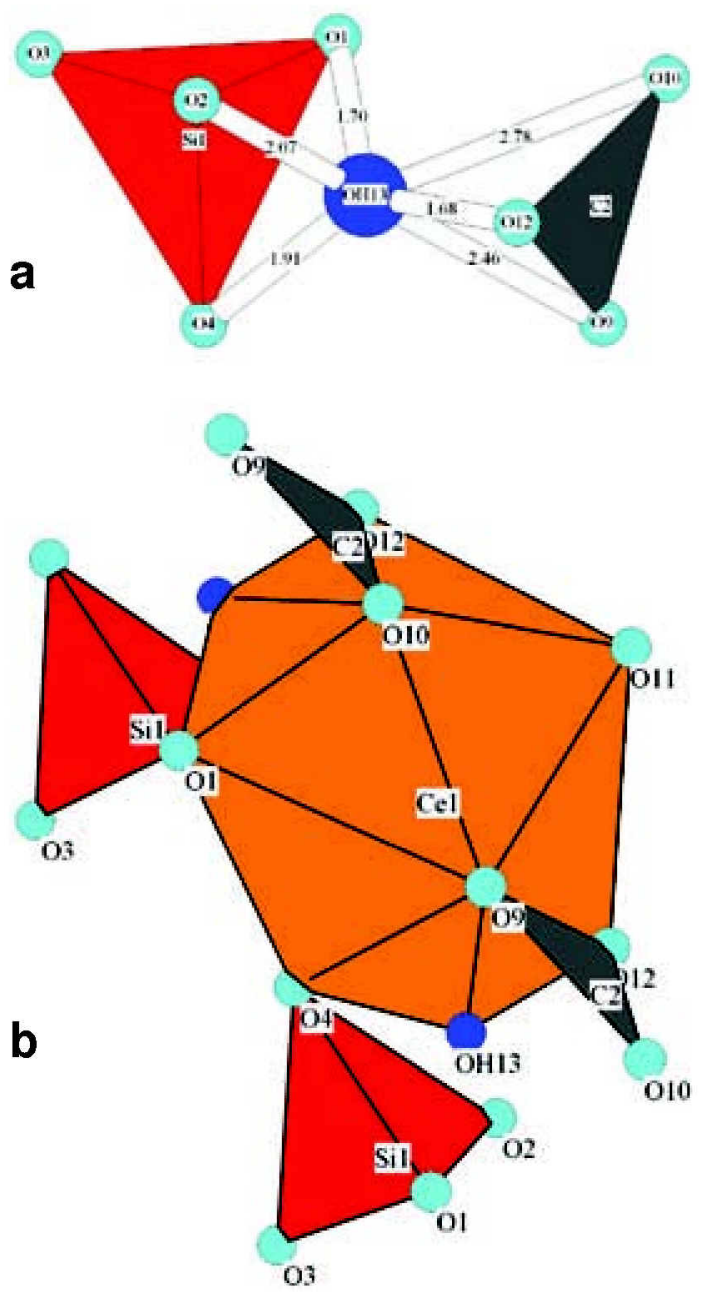

FIG. 5. The $O H 13$ atom site in tundrite-(Ce). (a) Distances $(\AA)$ between $\mathrm{OH} 13$ and $\mathrm{O}$ atoms in the $\left[\mathrm{SiO}_{4}\right]$ and $\left[\mathrm{CO}_{3}\right]$ groups. (b) The $\mathrm{Ce} 1$ polyhedron.

Tundrite-(Ce) has a distinctly layered structure (Fig. 6) consisting of three slabs of polyhedra: (1) a Na-TiSi-O slab (Fig. 7a), (2) a Ce-C-O slab (Fig. 7b), and (3) a Na-O- $\left(\mathrm{H}_{2} \mathrm{O}\right)$ slab (Fig. 7c). The slabs are cross-linked by independent $\left[\mathrm{CO}_{3}\right]^{2-}$ and $\left[\mathrm{SiO}_{4}\right]^{4-}$ groups. Grice (2005) described the affinity of the $\left[\mathrm{SiO}_{4}\right]^{4-}$ and $\left[\mathrm{CO}_{3}\right]^{2-}$ groups with regard to bond-valence matching. The $\left[\mathrm{SiO}_{4}\right]^{4-}$ group, having the higher Lewis base strength, is incorporated into the $\mathrm{Na}-\mathrm{Ti}$ slab, whereas the $\left[\mathrm{CO}_{3}\right]^{2-}$ group, with a lower Lewis base strength, is incorporated into the $\mathrm{Ce}-\mathrm{O}$ slab adjacent to the $\mathrm{Na}-\mathrm{O}$ slab.

\section{The role of hydrogen in tundrite}

Since the first description of tundrite by Semenov (1963), the amount of $\mathrm{H}_{2} \mathrm{O}$ and its speciation in the mineral have been in considerable doubt and have led to many erroneous conclusions. The $\mathrm{H}_{2} \mathrm{O}$ contents reported have varied from $15 \mathrm{wt} . \%$ (Semenov 1963) to $0 \mathrm{wt} . \%$ (Shumyatskaya et al. 1976). Much more realistic analyses are given by Shlyukova et al. (1973), 3.75 wt.\%, and Karup-Møller (1982), 2.2 wt.\%. From the present study, which includes IR spectra, TGA analysis and crystal-structure analysis, it is evident that there is hydrogen present as $[\mathrm{OH}]^{-}$, and possibly as $\mathrm{H}_{2} \mathrm{O}$. The hydroxyl anions may be in the O5 and O6 sites that are bonded only to Ti. The ratio of $\mathrm{O}^{2-}: \mathrm{OH}^{-}$is dependent on the $\mathrm{Ti}^{4+}: \mathrm{Nb}^{5+}$ ratio in these two $\mathrm{O}$ sites. Additional $[\mathrm{OH}]^{-}$or $\left[\mathrm{H}_{2} \mathrm{O}\right]$ can also be bonded to $\mathrm{Ce}$, and it would lie between the silicate and carbonate polyhedra. The spatial fit is tight between these two polyhedra, with O-O distances of 1.7 to $2.7 \AA$ (Fig. 5a). The actual mechanism of the site occupancy is not yet discernable, but one could imagine that an increase in the site occupancy of $O H 13$ could correspond to a

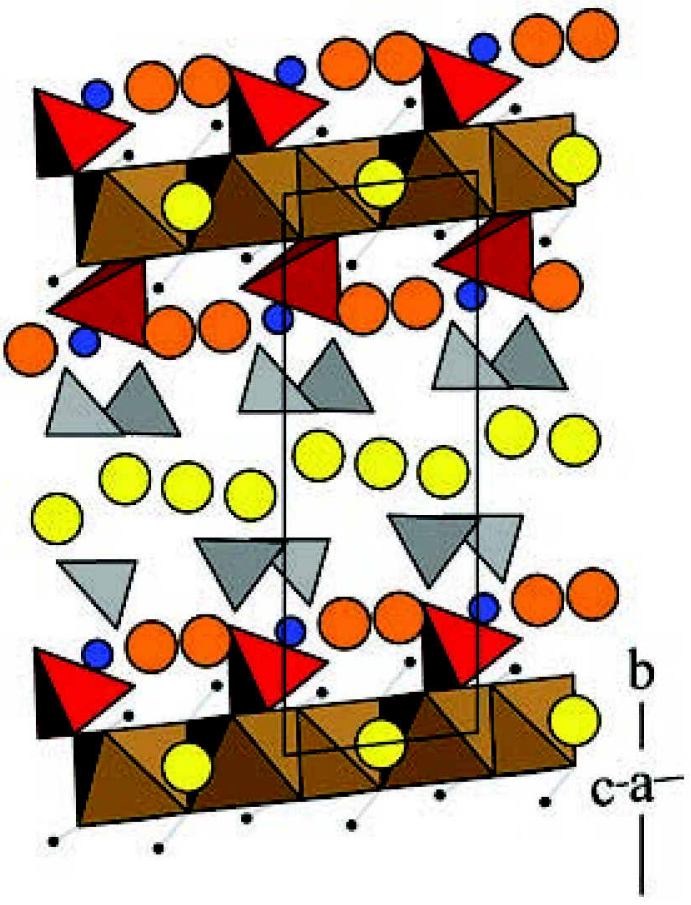

FIG. 6. The layered structure of tundrite-(Ce) projected along $[100]$. The $\left[\mathrm{TiO}_{6}\right]$ polyhedra are shown in brown, the $\left[\mathrm{SiO}_{4}\right]$ tetrahedra are red, the $\left[\mathrm{CO}_{3}\right]$ triangles are grey, $\mathrm{Ce}$ atoms in orange, $\mathrm{Na}$ atoms in yellow, $O H 13$ in blue, and $\mathrm{H}$ in small black circles. 

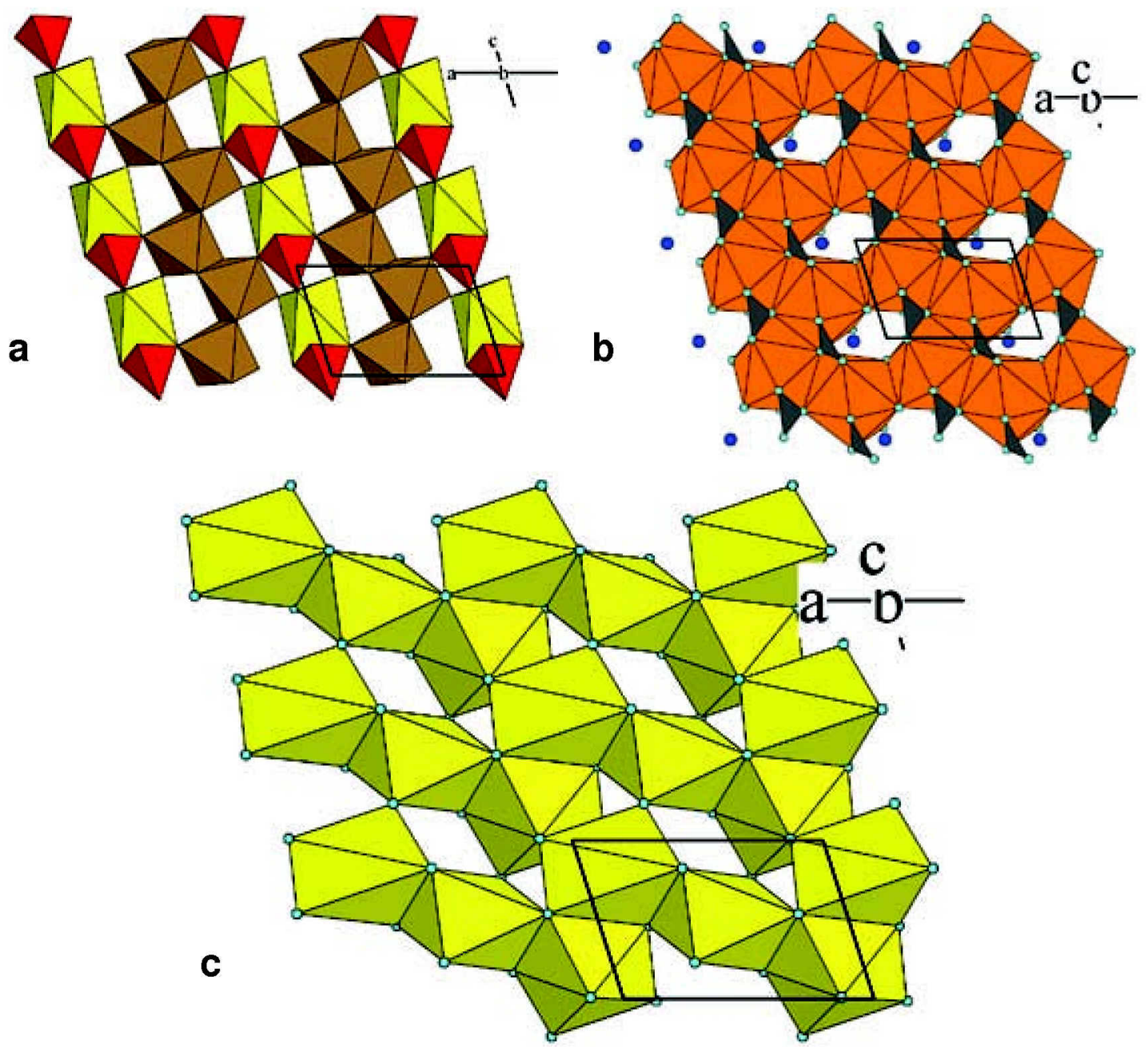

FIG. 7. Layers in the tundrite-(Ce) structure: (a) $\mathrm{Na1}$-, $\mathrm{Ti}$ - and $\mathrm{Si}$-centered polyhedra; (b) $\mathrm{Ce}$ - and $\mathrm{C}$-centered polyhedra; (c) $\mathrm{Na} 2$ - and $\mathrm{Na} 3$-centered polyhedra. The $\left[\mathrm{TiO}_{6}\right]$ polyhedra are brown, the $\left[\mathrm{SiO}_{4}\right]$ tetrahedra are red, the $\left[\mathrm{CO}_{3}\right]$ triangles are grey, $\mathrm{Ce}$ atoms in orange, Na atoms in yellow and $O H 13$ in blue.

decrease in the amount of either, or both, $\left[\mathrm{CO}_{3}\right]^{2-}$ or $\left[\mathrm{SiO}_{4}\right]^{4-}$ groups.

\section{ACKNOWLEDGEMENTS}

The authors gratefully acknowledge the cooperation of, and samples provided by, Dr. Pete Richards. The authors thank Dr. Frank Hawthorne, University of Manitoba, for the use of his four-circle diffractometer, Elizabeth Moffatt of the Canadian Conservation Institute, for the infrared spectrum, and Dr. Hazel Hunter, Natural History Museum. Helpful comments from Dr.
Frédéric Hatert as a reviewer, one anonymous reviewer, and Dr. Robert F. Martin, improved the quality of the manuscript.

\section{REFERENCES}

FARMER, V.C. (1974): The Infrared Spectra of Minerals. The Mineralogical Society, London, U.K. (Monograph 4).

GRICE, J.D. (2005): The structure of spurrite, tilleyite and scawtite, and relationships to other silicate-carbonate minerals. Can. Mineral. 43, 1489-1500. 
KARUP-MøLLER, S. (1982): Tundrite from Ilímaussaq alkaline intrusion, South Greenland. Neues Jahrb. Mineral., Monatsh., 481-494.

Pouchou, J.L. \& PICHOIR, F. (1984): New model quantitative for X-ray microanalysis. 1. Application to the analysis of homogeneous samples. Rech. Aérosp. 3, 13-38.

SEMENov, E.I. (1963): Mineralogy of rare earths. Izdat. Akad. Nauk SSSR, Moscow, USSR (209-210).

Semenov, E.I., Kazakova, M.E. \& Aleksandrova, R.R. (1967): The Lovozero minerals - nenadkevichite, gerasimovskite and tundrite - from Ilímaussaq, South Greenland. Meddel. Gronland 181, 1-11.

SHELdRICK, G.M. (1990): SHelXTL, a Crystallographic Computing Package, revision 4.1. Siemens Analytical Instruments, Inc., Madison, Wisconsin.
SHELdRICK, G.M. (1998): SADABS User Guide. University of Göttingen, Göttingen, Germany.

Shlyukova, Z.V., Vlasova, YE.V. \& KaZAKova, M.E. (1973): New data on tundrite. Dokl. Akad. Nauk SSSR 211, 426-429 (in Russ.).

Shumyatskaya, N.G., Voronkov, A.A., ILYUKhIN, V.V. \& BeLov, N.V. (1976): Tundrite, $\mathrm{Na}_{2} \mathrm{Ce}_{2} \mathrm{TiO}_{2}\left[\mathrm{SiO}_{4}\right]\left(\mathrm{CO}_{3}\right)_{2}-$ refinement of the crystal structure and chemical formula. Sov. Phys. Crystallogr. 21, 399-404.

Received June 12, 2007, revised manuscript accepted December 15, 2007. 